\title{
IDENTIFICATION OF PEDAGOGICAL CONDITIONS OF FORMATION OF THE WORLD OUTLOOK OF A CHILD IN THE FAMILY
}

\section{Oksana Yatsiv}

Based on the analysis of the peculiarities of formation and methodological aspects of the spiritual sphere of Ukrainians in Mykola Shlemkevych's legacy, the article reveals pedagogical conditions of building a child's worldview in the family - embodiment of spiritual and moral ideals in everyday life, unity with these high ideals, practicing such powerful upbringing methods as prayer, confession, communion with God (through high moral ideas in works of art, literature), communion, participation in worship, revealing the spiritual content of folk traditions, freedom of choice, religious faith, work on oneself, etc.

Here the emphasis is on children's independent participation in their upbringing. In this regard, the importance of ways of self-education - self-knowledge, self-analysis, self-observation, self-esteem, etc. - is revealed. This means finding and identifying democratic ways to build the spiritual world of a child in the family, relating to the expansion of the spirituality of Ukrainians in the works by M. Shlemkevych.

It is substantiated, that it is highly important to assimilate morality through the transition to an idealistic Christian system of values, which has always been supported by M. Shlemkevych. Therefore, it has been concluded, that a high level of improvement of the child's morality in the family can be achieved through the discovery of the Christian worldview and the recognition of the priority of spiritual and moral values. This is first used in communication with children, creating a highly spiritual atmosphere that would stimulate such well-known ways of practicing moral virtues as humility, forgiveness, repentance, fasting, prayer, confession, and others. Therefore, this will be facilitated not only by the external organization of the child's life in the family (for example, a good environment, participation in charities), but also by internal self-improvement (by self-restraint, restraint from negative thoughts, unworthy actions or bad intentions). The choice of the Christian strategy of education outlines both the general orientation of a child towards spiritual and moral values, and the stable position of adults in devotion to moral ideals, humanistic traditions

Keywords: pedagogical conditions, world outlook formation, child, M. Shlemkevych, spiritual development, humanism

(C) The Author(s) 2021

This is an open access article under the Creative Commons CC BY license hydrate

How to cite:

Yatsiv, O. (2021). Identification of pedagogical conditions of formation of the world outlook of a child in the family. ScienceRise: Pedagogical Education, 4 (43), 42-47. doi: http://doi.org/10.15587/2519-4984.2021.238095

\section{Introduction}

Changes in human consciousness, rejection of its materialization require the development of a new philosophy of education, justification of new approaches to education, analysis of publications of scientists of the past, including Ukrainian emigrants. Of course, it is important to take into account the social order and the European vector of determining the guidelines for the education of an individual, the direction of worldview ideas in the upbringing of children. The experience of past generations, the use of educational traditions contribute to the revival of the spirituality of the younger generation, the increase of national culture, guarantee the modernization of society and education, independence of decisions of each individual.

If traditions of a nation become the source of its educational ideal, the source of the transfer of its spiritual heritage, the conclusions of M. Shlemkevich about the need to serve God and the nation, putting a decent human with his/her moral virtues and laws of kindness and mercy in the center of attention mean return to spiritual roots, upbringing of children on the basis of humanism. After all, the worldview of each representative of the younger generation and the educational process is determined by what values are taken as a basis, what guidelines an individual prefers. Thus, the ethnopedagogical factor of child rearing is taken into account.

It is clear, that the basis of the spiritual revival of society, the humanization of each individual and all social institutions of education - educational institutions, families, public organizations - is the awareness of the Christian principles of education by all its subjects. Social justice and social love must become the main values, on which the reorganization of child's upbringing is based, and social peace is possible only if the internal unity of society.

Changes in the system of values, the transition to other ideals in the upbringing of a child lead to moral reorientations of society and each individual in particular, 
significant changes in society. Thus, the transformation of the system of values is a central issue of substantiation and analysis of all approaches to the education of an individual (it is not only compliance with the requirements of humanism, but also national education, democratization).

\section{Literary review}

Theoretical substantiation of the Ukrainian educational ideal is found in the works of G. Skovoroda, K. Ushinsky, G. Vashchenko, Galician teachers of the $30 \mathrm{~s}$, who embodied popular ideas about the most important thing we strive for in education - service to God and Ukraine, harmony of soul, body and mind. After all, God is the highest embodiment of goodness, love, honor, justice, and mercy. Prominent teachers offered some ways of self-education, revealed ways of moral improvement. G. Vashchenko drew attention to the fact that even the evangelical ideal of human presupposes active participation in the development of life (of him/herself and of all mankind), and above all - for his/her own happiness. A Galician pedagogue O. Dzerovych noted that the key to the formation of the spirituality of an individual is the organization and change of various activities and communication (especially activities in situations involving the expression of compassion, mercy). Note that important ways to develop the spiritual strength of human, his/her moral improvement were named by G. Skovoroda: spiritual exercise to learn not to feel sorry for the lost, to gain true humility, contempt for wealth, escape from the crowd and worldly affairs, fasting and restraint and more.

Theoretical substantiation of modernization processes in modern Ukrainian education, which concern the improvement of its priorities and values, are laid down in the works of I. Bekh, G. Vasyanovych, I. Zyazyun, V. Kremen, O. Savchenko, O. Sukhomlynska and others. A modern pedagogue O. Vyshnevsky emphasizes that the moral degradation of young people occurs through the "materialization" of consciousness, and, according to O. Vyshnevsky, important ways of spiritual growth, a kind of factor in the spiritual sphere of human is any communication of the child's soul with good people, highly spiritual art, participation in worship, charity, examination of conscience, overcoming difficulties, participation in work.

O. Savchenko emphasizes: "Humanistic image of education - the organization of joint life, creating conditions for self-development, care for understanding the inner world of students, their successful socialization in society" [1]. The scientist characterizes a new understanding of the attitude to nature and humanity, which "corresponds not to the ideal of anthropocentrism, but the idea of eco-evolution, the joint evolution of nature and society" [1].

T. Pirozhenko's research highlights the definition of the child's worldview and the educational influence of the family on a child: "We need a deep faith that the child can do everything, we just need to learn to instill in him/her faith in his/her own strength, carefully and indirectly help him/her to create him/herself "[2]. The authors also emphasize that "... a child needs a close adult for full-value growth, who does not forbid, does not re- strict, but gives freedom, does not fight "against", but forms "for", does not suppress, but glorifies, does not dictate, but teaches by his/her own example, does not demand, does not force, but asks, consults and advises, divides in half inspiration, joy, sorrow, failure"[2]. After all, "loving parents should be aware that the child's development occurs in the process of overcoming obstacles" [2]

I. Bila emphasizes the responsibility of parents to society and the state for the development, upbringing and education of children, preservation of their lives, health, human dignity. The scientist emphasizes: "Only under the condition of a conscious and responsible attitude to parenthood, family upbringing, a child will grow up physically, mentally and spiritually healthy, and the formation of his/her worldview will be positive and full" [3].

Regarding methodological aspects of the development of the spiritual sphere of Ukrainians in the legacy of Mykola Shlemkevych, the opinions of P. Berko and M. Dzera [4] who study the worldview of the scientist through the prism of anthropological attitude and emphasize the traditional vision of Ukrainians of their lives and the need to develop life guidelines and values, which would take into account his prospects and worldviews of Ukrainians, are significant. S. Grabovsky, V. Khramova and others reveal the significance of M. Shlemkevych's views in the context of highlighting the peculiarities of the Ukrainian mentality. O. Onatsky analyzes fundamental views of the scientist on the Ukrainian emotionality; O. Kulchytsky - on the worldview of Ukrainians; B. Tsymbalisty - on the specifics of traditional family life. At the same time, despite the existing developments, the ideological pedagogical ideas of M. Shlemkevych were not the subject of a separate study. Mykola Shlemkevych's scientific and educational activities and worldview ideas were not the subject of a separate historical and pedagogical study of children's upbringing in Ukraine, the strategic guidelines and values of the child's moral and national life in the family, their hierarchy and other methodological issues.

Humanistic perspectives of education development and the need to support humanism in education as a theory of ensuring attention to an individual are emphasized by M. Buxarrais and F. Esterban [5]. They emphasize the importance of focusing on moral values that lead to the humanization and democratization of partners in education. Scientists see the satisfaction of human's high moral needs for the formation of his/her spirituality in the organization of various activities, followed by their analysis in communication.

The specific vision of these scholars corresponds to the ideas of W. Veugelers [6] about the moral development of an individual and its relationship with citizenship in the context of humanistic perspectives on the formation of educational priorities. Participation in communication with people on various topics is often used to assess the quality and effectiveness of education.

G. Drew's reasoning [7] also testifies to the importance of humanistic theory in education and humane influences of the environment in the formation of the value attitude of an individual to its future activities. It depends on upbringing how much such a desire to work will develop. 
Scientists Peter Wolf, Julia Christensen Hughes and others [8] proposed a model of systematic evaluation of curricula, which largely depends on trends in increasing the responsibility of an individual and the emphasis on an independent approach to the activity, which provides its quality preparation for the implementation of vital functions. Researchers reveal the features of innovation processes in European education in the context of improving curricula and the transition from content that emphasizes knowledge to broad competencies, when the emphasis is on the capabilities of an individual. It is no coincidence that today we are talking primarily about the activities of a child, which makes it impossible for an adult to become a consultant in the child's self-preparation [9].

\section{Research aim and tasks}

The aim of the article is to identify the pedagogical conditions for the formation of the child's worldview in the family, the importance of faith, religion, beliefs, freedom, work for the development of human spiritual strength and their role in shaping the consciousness of Ukrainians.

To achieve this goal, the following tasks are set:

1) To determine the pedagogical conditions for the formation of the worldview of a child in the family in the context of humanization of his/her life;

2) To reveal the importance of faith, religion, beliefs, freedom, work for the process of development of spiritual forces of a human;

3) To identify the features of the practical implementation of the child's worldview in the family.

\section{Materials and methods}

In order to determine the pedagogical conditions of forming the child's worldview in the family in the context of humanization of his/her life (and as a manifestation of the policy of humanitarian development and modernization of society according to European trends by means of humanization of human life), we used such research methods as logical-historical analysis of $\mathrm{M}$. Shlemkevich's pedagogical ideas., synthesis of information from scientific sources, induction and deduction, study of psychological and pedagogical and methodological literature, pedagogical experience, solving life situations, conversations with children in the family (to clarify the state of formation of their consciousness).

The study of pedagogical literature (domestic and foreign), historical sources, comparative analysis revealed the importance of faith, religion, beliefs, freedom, work for the development of human spiritual strength.

Logical-historical analysis, observation, systematic analysis of M. Shlemkevych's works in the context of highlighting the peculiarities of the Ukrainian character, way of thinking, flow of emotions, etc. and methodological aspects of the development of the spiritual sphere of an individual in the family will help to solve the problem of determining the practical implementation of the child's worldview in the family.

\section{Research results and their discussion}

The basis of the formation of the child's consciousness is the priority of morality in all spheres of his/her life. This reorientation in human upbringing means that morality is a healthy core of a person who has mastered the basics of educational truths. Of course, moral information (moral knowledge, skills, abilities) are not elements of moral consciousness and education, as it is the basis for this consciousness, but it is generally accepted that the assimilation of information is the first stage of formation of the child's consciousness. Therefore, the semantic aspect of consciousness (and education) is moral feelings (eg. responsibility, duty, dignity, honor), emotions, needs, judgments, experiences, ideas, orientations, ideals, beliefs.

The moral climate in a family, where there is a highly spiritual atmosphere, when it is a shame to do work carelessly, to deceive, to live at the expense of others, when revenge, anger, betrayal are excluded, depends on what kind of person is involved in the humanization, what moral guidelines determine his/her life and behavior. Generous, friendly attitude to a person means such love for him/her that allows to see the good in him/her, to rely on him/her (an act should be condemned, not a person him/herself, because he/she cannot be "bad", although he/she can be wrong). Therefore, a child must be convinced of the benefits of peace, reconciliation of people, their equality, forgiveness - such a peaceful consciousness is a manifestation of human freedom, the right to their own culture. We need the support of good and condemnation of unworthy deeds.

The choice of value orientations that accompanies each person (in his/her pursuit of progress, harmony, selfrealization and self-determination in life) involves "the formation of intentions and skills of conflict-free life in society, respect for the rights and freedoms of each person in the minds of pupils." As O. Savchenko rightly notes, "modern understanding of humanistic values of education is based on anthropological and sociocultural coordinates", because human is not a means but a goal, and pedagogical realization of such values involves proper assessment of "human natural basis" and "improvement of general personality culture, attachment to national and universal values, and this requires strengthening the cultural orientation of education "[1].

The humanization of the Ukrainian consciousness also means the humanization of the relationship between people, taking into account their individual characteristics, the appropriate level of self-realization. It requires the ability to empathize, to be patient, to find words of gratitude, to express warm wishes, to understand a person, to evaluate his/her actions fairly and to believe that he/she will be able to become better.

From the pedagogical point of view, the issues of moral transformation of a person and deep internal transformational processes that take place in a person as a result of conscious value orientation and the choice of appropriate motivational priorities are valuable. Giving preference to the spiritual landmarks of an individual, recognizing the priority values that form the basis of its moral virtues and laws of kindness and mercy, returning to the spiritual roots of the people on the basis of humanism put the focus on a decent person, as M. Shlemkevych said. After all, a person's spiritual culture is manifested in his/her relationships with other people, the ability to understand another person, respect, love $\mathrm{him} / \mathrm{her}$, as well as in relation to family, nation, com- 
munity. The traditions of the people become a source of spirituality of a human, his/her educational ideal, a factor in the transfer of his/her spiritual heritage.

Thus, the methodological foundations of the worldview of Ukrainians, found in the work of M. Shlemkevych, allow to determine priorities in relation to a human, his/her nature, to understand coexistence with the world, other people and God, as well as to determine the factors of successful youth education. Awareness of the importance of the ideals that Christianity gives us is associated with Christian values.

M. Shlemkevych considered freedom of choice to be the most important condition for determining a certain decision, a kind of self-determination in the modes of action. After all, in order to satisfy spiritual needs and maintain one's own dignity, a person first of all needs freedom. The researcher insisted on the importance of freedom as an important factor in the formation of personality. In this regard, such methods of self-education of a child as self-analysis, self-knowledge, self-observation, etc. are of great importance, which means identifying such democratic ways of forming the child's spiritual world in the family, which exclude pressure, imposition, relate to the expansion of the spirituality of every Ukrainian in the work of M. Shlemkevych.

This strategy of raising a child is in line with the following ideas: "Humane and personal pedagogy and involves the creation of such an atmosphere of the developmental field, when a child feels like an adult exactly where he/she is not yet it, but a child. Of course, this is possible only within the framework of subject-subject communication" [2]. The scientist notes: "In any pedagogical process there is a danger of suppression of the child's freedom. The educational process itself contains certain norms and rules that a child must obey. And in family upbringing there are also certain internal, intrafamily rules of coexistence, which a child must accept and obey them. These requirements do not depend on desires, needs and individual preferences of the child, and their observance by all family members is perhaps the first need of adults. For the most part, parents are simply convinced that a child not only can, but must learn to live in a family "like everyone else" as soon as possible... It is clear, that creating such a microclimate requires or presupposes true parental love from adults. And it carries a high respect for the little creature of God, a deep faith in his great potential, which will respond to parental grace, trust and support. And in the atmosphere of such relations a child easily reveals individual unique qualities, inclinations and their features... This is the main meaning of humane and personal communication between an adult and a child "[2].

Therefore, the teacher emphasizes the importance of global responsibility for the lives of others and the formation of such a worldview. If the family and family ties permeate the whole life of a child, then he/she, of course, becomes a person in terms of belonging to a family, a successor of pedigree traditions, a heir of a particular ethnic group. The child's discovery of his/her own "Me" becomes the basis of the pupil's self-determination in his/her relationships with other people, family members. And parents can create such conditions when a child seeks to preserve the unity of the family, to the dominance of love and harmony.

M. Shlemkevych's pedagogical approaches to the child's ideological training (including orientation to the educational ideal, values of upbringing) provide for the recognition of the moral priority and the need to consider within it the values of national life, grew on their own traditions and embodie popular ideas about the main incentives and expectations Ukrainians - service to God and Ukraine, the nation. The only basis for building a system of family upbringing, of course, should be the national culture that combines customs, traditions, art, crafts, religion, on the basis of which the national consciousness of a child is formed. Human's ideas about the cultural, democratic environment, the realization of his/her chosen lifestyle, his/her own achievements confirm his/her creative nature, the desire for freedom and self-expression, selfrealization and become the basis of humanism.

Usually a person goes to the level of spiritual development and growth of moral values, cultivating love for the environment. Analyzing the activities of the social community of the family, M. Shlemkevych substantiated its decisive role in the formation of the national identity of the Ukrainian human.

The essence of the formation of consciousness of every Ukrainian person follows from the needs of strengthening the family. In addition, it is important to focus on the values that ensure the life of the family. It is about the ability to give in to one's own interests, to care for family members and the interests of the nation. It is the duty of the family to assimilate moral and national values, which, however, does not mean less attention to the formation of morality in the family, the education of character, which provides quality preparation for life in it.

M. Shlemkevych argued that the formation and development of personality are carried out through various activities by means of national culture. Although in the field of national culture there are different types of activities of an individual, but the development of its worldview, its emotional enrichment is determined by the implementation of cultural, educational and creative developmental function.

Therefore, the ways of establishing spiritual values and means of forming the spiritual world of a child were considered by prominent teachers from the standpoint of humanization and democratization of personal education. The humanization of the consciousness and actions of the child's personality is ensured primarily by his/her behavior in the family, which requires the expression of compassion, kindness, mercy, love, etc.

Ways to affirm spiritual values and other ideals of good, to find means of forming humanity, i.e. humanization, are important for the child's consciousness. After all, humanism as a system of views on human as the greatest social value and the creation of conditions for his/her full life, physical and spiritual development involves the idea of priority and absoluteness of moral values, the impossibility of interpreting their relativity. This creates a basis for the expansion and enrichment of the child's inner world, its maturation and deep penetration into the world of moral values, which means the fulfillment of his/her vital role, as well as development and self-development. 
Their positive impact on the education of a conscious citizen will be determined by shifting the emphasis to the formation of humanity in a human him/herself. This means that humanization is primarily interpreted as self-humanization, which leads to self-determination and self-realization in life. As a result, fathers and mothers cannot impose their beliefs, destroy freedom of choice, or commit violence. They are designed to provide moral assistance to a person, to help a person to know $\mathrm{him} /$ herself and realize the need to form a personality, so it is necessary to overcome their own weaknesses and take responsibility for their actions.

The Ukrainian educational tradition took into account the effectiveness and reliability of education based on faith. If faith is a need of a human, then he/she each time multiplies in a sense of faith him/herself. And the very effort to become better, to get closer to God is the beginning of true spirituality. Therefore, education involves a difficult path from blind faith through doubt, search, struggle in the soul and the test to stable beliefs, unshakable ideals, a strong worldview. Religious faith reveals the need to realize the hidden possibility in a person to do what seems impossible, inspires a person, raises above the circumstances. M. Shlemkevych wrote that faith illuminates the most striking examples of human heroism, and the religious soul seeks the presence of God everywhere.

According to such ideas about faith as an important pedagogical condition for the formation of the worldview of Ukrainians, M. Shlemkevych (as a religious person) considered repentance, suffering, forgiveness, overcoming obstacles, peace (as opposed to uncertainties and anxiety), testing oneself in faith as natural ways of developing one's spiritual strength. At the same time, in order to find the truth and justice in life, M. Shlemkevych also recommended optimism, building trust in Ukrainians, faith in the ideals of good, a better future. Of course, significant internal work on oneself becomes a necessity in their implementation.

Another important pedagogical condition for the formation of the child's worldview is the work of an individual, which has always been considered conscious and focused on a particular object (activity), which is to apply its abilities, is a necessity and a way to selfdevelopment and service to others, family, to the people and is therefore noble. In addition, in connection with the implementation of the tasks of spiritual growth of a child, it is necessary to address the issues of providing conditions for independent work. Note that the opportunity to express their own independent opinion is associated by $\mathrm{S}$. Rusov with the formation of character, will in the family.

The idea of finding the way to the truth, ways to achieve goals (especially by one's own efforts and sacrificial work) was pursued by M. Shlemkevych with a firm conviction to prevent reconciliation with deception, immorality, injustice, inadmissibility to encroach on other people's peace and rights or cause them pain and suffering. According to M. Shlemkevych, conversation, discussion, which helps to form beliefs, ideals, etc., can be subordinated to this idea. Therefore, we take into account important ways of developing the child's spirituality in the family - prayer, confession, communion, participation in worship, overcoming difficulties, communication with God through highly spiritual literature, art, participation in charity, realization of moral ideals in relationships with others. All these statements about the pedagogical ideas of M. Shlemkevych, which provided for a return to spiritual origins and meant reliance on faith in approaches to education, were determined from published sources by O. I. Yatsiv (for example, [10, 11]).

The advantages of the study are the features of the Ukrainian mentality, traditional views on spirituality, adherence to faith, freedom, etc. (respectively, the disadvantages are ignoring these features in the lives of individuals). Our research is limited to families that care about the spiritual development of each child, uphold spiritual and moral values, and see no alternative to democratic ways of forming consciousness.

Emphasis on the need to ensure the status of the subject for a child, the importance of independent participation of children in their upbringing and ways of selfeducation allow us to outline further prospects for research, which means finding and identifying democratic ways to shape the spirituality of Ukrainian children in the family (including works of M. Shlemkevych), which would strengthen the qualitative understanding of the essence of humanistic transformations in education.

\section{Conclusions}

1) The pedagogical conditions for the formation of the child's worldview in the family are the realization of spiritual and moral ideals in everyday life, close combination with them through prayer, confession, communication with God, high moral ideas, communion, participation in worship, revealing the spiritual content of literary works, folk traditions, art, religious faith, freedom of choice, work on oneself. It is proved, that a high level of improvement of the child's morality in the family can be achieved by identifying the Christian worldview, recognizing the priority of spiritual and moral values, humanistic transformations in education, which mean attention to a child, his/her inner world, needs, inclinations, opportunities and also organization of communication with other children, creating a highly spiritual atmosphere of life. Just the realization of the child's chosen lifestyle, his/her own achievements confirm his/her creative nature, the desire for freedom and self-expression, selfrealization and become the basis of humanism.

By their own example, parents affirm the ideals they instill in their children, try to lead a healthy lifestyle and be a role model. Of course, they must be characterized by an appropriate level of intelligence and decency.

2) The revealed great importance of faith, religion, beliefs, freedom, work for the development of human spiritual forces is confirmed by M. Shlemkevich's worldview ideas regarding the establishment of the Christian faith in the minds of young people, focus on moral and national values, folk traditions, understanding of freedom, positive attitude to work.

3) The features of the practical implementation of the child's worldview in the family (according to the works by M. Shlemkevych on methodological aspects of the spiritual sphere of personality) are taking into account the qualities of the Ukrainian character, traditional family status, idealistic Christian value system, typical of the Ukrainian family, recognition of morality, religiosity, humane treatment of a small child, love for mother, etc. 


\section{References}

1. Savchenko, O. (1996) Tsili y tsinnosti reformuvannia suchasnoi shkoly. Shliakh osvity, 1, 20-23.

2. Pirozhenko, T. O. (Ed.) (2012) Stanovlennia vnutrishnoi kartyny doshkilnyka. Kirovohrad: Imeks-LTD, 236.

3. Bila, I. (2016). Formuvannia svitohliadu dytyny v umovakh simeinoho vykhovannia. Vykhovatel-metodyst doshkilnoho zakladu, 7, 15-20.

4. Berko, P. H., Dzera, M. M. (2016). Nicholas Shlemkevych outlook in the light of anthropological settings. Scientific Messenger LNUVMBT named after S.Z. Gzhytskyj, 18 (2 (69)), 238-245.

5. Buxarrais, M. R., Esterban, F.; Veugelers W. (Ed.) (2011). Moral Education from a Humanist Perspective. Education and humanism: Linking autonomy and humanity. Rotterdam: Sense Publishers, 47-65. doi: http://doi.org/10.1007/978-94-6091-577-2_4

6. Veugelers, W. (Ed.) (2011). A Humanist Perspective on Moral Development and Citizenship Education. Education and humanism: Linking autonomy and humanity. Rotterdam: Sense Publishers, 9-34. doi: http://doi.org/10.1007/978-94-6091-577-2_2

7. Drew, N. (2020). What is the Humanistic Theory in Education? Available at: https://helpfulprofessor.com/humanisttheory-in-education/

8. Wolf, P., Hughes J. C. (Eds.) (2007). Curriculum Development in Higher Education: Faculty-Driven Processes \& Practices: New Directions for Teaching and Learning (J - B TL Single Issue Teaching and Learning). New Directions for Teaching and Learning. Number 112. San Francisco: Wiley Subscription Series, Inc., 122.

9. Taylor, M. (2010). Teaching Generation Next: A Pedagogy for Today's Learner's. A Collection of Papers on Self-Study and Instructional Improvement, 192-196.

10. Yatsiv, O. (2018). Mykola Shlemkevych pro etnopedahohichni zasady formuvannia osobystosti. Drohobych: Red.-vyd. viddil DDPU imeni Ivana Franka, 66.

11. Yatsiv, O. (2018). Dukhovno-moralni oriientyry stanovlennia svitohliadu ukraintsiv u spadshchyni Mykoly Shlemkevycha. Pedahohichni nauky, 84, 29-33.

Received date 20.05.2021

Accepted date 22.06.2021

Published date 30.07.2021

Yatsiv Oksana, PhD, Lecturer, Department of General Pedagogy and Preschool Education, Drohobych Ivan Franko State Pedagogical University, I. Franka str., 24, Drohobych, Ukraine, 82100

E-mail: 30x05x@gmail.com 